\title{
Considering the Role of Psychological Stress on Sleep Quality in Individuals with Subclinical Hypothyroidism [Letter]
}

This article was published in the following Dove Press journal: Risk Management and Healthcare Policy

\section{Inayat Hussain Khan (ID \\ Tasnim Chowdhury \\ Samiul Oliver Khan (D)}

Faculty of Medicine, St George's Hospital Medical School, London, UK
Correspondence: Inayat Hussain Khan Faculty of Medicine, St George's Hospital Medical School, Cranmer Terrace, London SWI7 ORE, UK

Tel +442086729944

Email mI506I31@sgul.ac.uk

\section{Dear editor}

We read the article by Song et al with great interest ${ }^{1}$ and thank the authors for exploring the relationship between subclinical hypothyroidism and sleep quality in a large general population. Subclinical hypothyroidism is a challenge to both patients and healthcare systems; potential sequelae include progression to hypothyroidism and cardiovascular disease. ${ }^{2}$ There are few studies exploring the relationship between subclinical hypothyroidism and sleep quality despite its extensive impact on health, as discussed in the current study. ${ }^{1}$

The authors took great care in recruiting individuals from the Health Promotion Center of West China Hospital. Individuals with previous thyroid disease, other medical conditions and those who were pregnant were excluded to ensure the effects of subclinical hypothyroidism could initially be evaluated in a general population. Potential confounding variables such as diabetes, alcohol consumption and smoking were adjusted for when assessing sleep quality.

Despite this, the authors did not consider psychological stress in participants. Stress is common amongst the general population and should not be overlooked due to its negative effects on sleep as discussed previously. ${ }^{3}$ Similarly, the effects of psychological stress on the Hypothalamic-Pituitary-Thyroid axis have also been documented. ${ }^{4}$

One could argue that some of the questions in the Pittsburgh Sleep Quality Index used in the current study could acknowledge some manifestations of stress. However, we recommend that a more formal clinical tool, such as the Perceived Stress Scale should be utilized. ${ }^{5}$ This would allow for a quantifiable measure of stress in participants, which could subsequently be adjusted for in regression models.

Future studies evaluating subclinical hypothyroidism and sleep quality should consider participants' stress levels. Although psychological stress is not a formal mental or physical health diagnosis, it should be measured using an appropriate tool when evaluating sleep quality as it is a confounding variable.

In conclusion, the impact of stress on sleep quality should not be overlooked in populations with subclinical hypothyroidism.

\section{Disclosure}

The authors report no conflicts of interest in this communication. 


\section{References}

1. Song L, Lei J, Jiang K, et al. The association between subclinical hypothyroidism and sleep quality: a population-based study. Risk Manag Healthc Policy. 2019;12:369-374.

2. Fatourechi V. Subclinical hypothyroidism: an update for primary care physicians. Mayo Clin Proc. 2009;84(1):65-71. doi:10.4065/84.1.65
3. Partinen M. Sleep disorders and stress. $J$ Psychosom Res. 1994;38:89-91. doi:10.1016/0022-3999(94)90139-2

4. Mizokami T, Wu Li A, El-Kaissi S, Wall J. Stress and thyroid autoimmunity. Thyroid. 2004;14(12):1047-1055. doi:10.1089/ thy.2004.14.1047

5. Cohen S, Kamarck T, Mermelstein R. A Global Measure of perceived stress. J Health Soc Behav. 1983;24(4):385. doi:10.2307/ 2136404

Dove Medical Press encourages responsible, free and frank academic debate. The content of the Risk Management and Healthcare Policy 'letters to the editor' section does not necessarily represent the views of Dove Medical Press, its officers, agents, employees, related entities or the Risk Management and Healthcare Policy editors. While all reasonable steps have been taken to confirm the content of each letter, Dove Medical Press accepts no liability in respect of the content of any letter, nor is it responsible for the content and accuracy of any letter to the editor.

Risk Management and Healthcare Policy

Dovepress

\section{Publish your work in this journal}

Risk Management and Healthcare Policy is an international, peerreviewed, open access journal focusing on all aspects of public health, policy, and preventative measures to promote good health and improve morbidity and mortality in the population. The journal welcomes submitted papers covering original research, basic science, clinical \& epidemiological studies, reviews and evaluations, guidelines, expert opinion and commentary, case reports and extended reports. The manuscript management system is completely online and includes a very quick and fair peer-review system, which is all easy to use. Visit http://www.dovepress.com/testimonials.php to read real quotes from published authors. 